This is an electronic reprint of the original article. This reprint may differ from the original in pagination and typographic detail.

Author(s): Dlaske, Kati

Title: $\quad$ Semiotics of pride and profit: interrogating commodification in indigenous handicraft production

Year: $\quad 2014$

Version:

Please cite the original version:

Dlaske, K. (2014). Semiotics of pride and profit: interrogating commodification in indigenous handicraft production. Social Semiotics, 24(5), 582-598.

https://doi.org/10.1080/10350330.2014.943459

All material supplied via JYX is protected by copyright and other intellectual property rights, and duplication or sale of all or part of any of the repository collections is not permitted, except that material may be duplicated by you for your research use or educational purposes in electronic or print form. You must obtain permission for any other use. Electronic or print copies may not be offered, whether for sale or otherwise to anyone who is not an authorised user. 


\title{
Semiotics of pride and profit: Interrogating commodification in indigenous handicraft production
}

\author{
Kati Dlaske, University of Jyväskylä
}

\begin{abstract}
This study investigates the shifting terrain of pride, profit and power relations in minority language communities under contemporary globalisation. While "pride" associates linguistic-cultural heritage with identity and preservation, "profit" views these as sources of economic gain. In contemporary late capitalism, "pride" seems to be increasingly giving way to "profit". Arguing that this transformation needs to be interrogated in terms of complexity and that a detailed, multilayered semiotic analysis can open a privileged window for such an inquiry, this study combines critical multimodal discourse analysis and an ethnographic approach to analyse processes of semiotic commodification in handicraft production in the indigenous minority language community of the Sámi in northern Lapland. The investigation focuses on the activities of an innovative Sámi artist and entrepreneur, and within these a range of paper notebooks, which are, although designed by the Sámi artist and sold in her handicraft shop in Lapland, produced by women living at the border of Thailand and Laos. The investigation illuminates two critical shifts: how the move towards profit can open up space to contest the ownership of pride within an ethnic community. Second, how this move makes way for new, globalised modes of production of 'indigenous handicrafts' and creates global vectors of power, engaged in both empowerment and exploitation, in the production of both pride and profit. The study thereby contributes to the understanding of the increasingly complex power relations and the ambivalence and multiple effects of practices constituting the apparent shift from "pride" to "profit".
\end{abstract}

Keywords: commodification; late capitalism; linguistic minorities; handicrafts; multimodal discourse analysis; ethnography

\section{Bionote for the author}

Kati Dlaske is a post-doctoral researcher in discourse studies at the Department of Languages at the University of Jyväskylä, Finland. She earned her PhD in German Language and Culture at the University of Jyväskylä in 2011. Since then, she has been working as a researcher in the Peripheral Multilingualism project funded by the Academy of Finland. Her research interests include issues relating to multilingualism and minoritised language communities, power and late capitalism, and theoretical and methodological questions relating to critical multimodal discourse studies. Her research has been published in Discourse and Communication, Sociolinguistica, Journal of Multicultural Discourses and Critical Approaches to Discourse Analysis Across Disciplines (CADAAD). 


\section{Introduction}

In recent years, sociolinguistics have started to document the changes emerging in minority language communities that are evidence of what Heller \& Duchêne (2012a) have termed a shift from pride to profit in connection with the rise of the globalised new economy (e.g. Heller 2003, 2011; Heller \& Duchêne 2012b; McLaughlin 2013; Pietikäinen 2013; Pietikäinen \& Kelly-Holmes 2011). While the trope of pride associates the cultural heritage of linguistic minorities with rights, identity, and cultural and linguistic preservation, that of profit marks an orientation towards treating linguistic and cultural resources as a source of economic gain (Heller \& Duchêne 2012a).

One site witnessing this shift is Sámiland, home to the indigenous, minority language people, the Sámi, in northern Lapland. In Lapland, like in many other globally peripheral multilingual regions, heritage tourism is becoming an increasingly important means of livelihood (cf. Pujolar \& Jones 2012). The major selling point of tourism in Lapland is Sámi culture, aspects of which are drawn upon in ever new ways in the construction of the tourist experience (cf. Kauppinen 2014; Pietikäinen \& Kelly-Holmes 2011; Pietikäinen 2013). In this process, the realm of Sámi handicrafts, traditionally serving the practical needs of everyday life and signaling the preservation of cultural traditions, has increasingly become a part of the tourist industry. New, commercial handicraft brands aimed at tourist markets are emerging alongside Duodji, the traditional Sámi handicraft, the embodiment par excellence of the trope of pride.

If these developments appear at first glance to be not much more than a move towards selling out the indigenous culture to global capitalism, a closer look shows that this view is inadequate. What is needed to really understand these processes is an approach capable of addressing not only the increasingly complex power relations and shifting positions of social actors in contemporary late modernity, but also the ambivalence and multiple effects of the practices constituting these developments (cf. also Heller and Duchêne 2012a; del Percio \& Duchêne 2012; Pujolar \& Jones 2012). To get at the de facto complexity characterising the shifting terrain of pride and profit and power relations in the realm of Sámi handicrafts under contemporary globalised conditions, the present study, part of a larger research project ${ }^{i}$, draws on an ethnographic approach (cf. Heller 2008) and "zooms in" (Hult 2010) on the activities of one salient actor, a Sámi artist and entrepreneur living and working in the village of Inari, the centre of Sámi culture and tourism in Finland. What makes this particular actor especially interesting for the present study, are the ways in which she in her work both draws on and transgresses the Sámi cultural traditions.

As has been argued in previous studies, language plays a key role in the shift from pride to profit, not only because of its newly found value as a commodity, but also because of its function as a resource for commodification through the discursive mediation, or semiotisation, of goods (e.g. Heller 2003, 2011; Pietikäinen 2010; Pietikäinen \& KellyHolmes 2011; cf. Kopytoff 1986; Lash \& Urry 1994; Thurlow \& Jaworski 2010, 7). Despite this recognition, much of the research, especially on tourism and handicrafts, has tended to focus on large data sets and broader overviews leaving thereby detailed and systematic analyses of the semiotic resources drawn upon in these processes in the background (e.g. Heller 2011; Pujolar \& Jones 2012; see, however, e.g. Heller \& Pujolar 2009; Pietikäinen \& Kelly-Holmes 2011). To embrace the potential of a detailed and multilayered semiotic analysis, the present study focuses on one particularly revealing site among the various activities of the above mentioned artist-entrepreneur, namely a range of paper notebooks, 
which represents a significant part of the handicraft production sold in this artistentrepreneur's (tourist) handicraft shop in Inari. What makes these books particular, is, that although they are designed by the Sámi artist and sold in her shop in northern Lapland, they are produced by women living at the border of Thailand and Laos. The analysis draws on multimodal critical discourse analytical approaches (e.g. Blommaert 2010; van Leeuwen 2008; Pennycook 2010) and a variety of ethnographic data and investigates the ways in which the semiotic resources drawn upon in the commodification of the notebook collection are also linked to a number of other activities, concerns and aspirations, pointing less to the trope of profit than, in different ways, to that of pride, thus making the notebooks a multidimensional and ambivalent nexus of social processes and power relations.

The paper is divided into seven sections. In the next two sections, Section 2 and 3, I will first discuss the central theoretical starting points of the study and then look at developments in the realm of Sámi handicrafts. Then, in Sections 4 and 5, I introduce the methodology and data and set the core data, the range of notebooks, in its ethnographic context. Section 6 examines the meanings, functions and connections of the semiotic resources drawn upon in the commodification of the books, after which Section 7 concludes with a critical consideration of the new constellations of pride, profit and power relations that have emerged from the analysis.

\section{The new economy, commodification and globalisation}

Heller \& Duchêne (2012a) tie the shift from the trope of pride to that of profit in minority language communities to the expansion of the new economy. In this connection, the new economy refers to a number of changes in production processes that have taken place in response to the saturation of markets and international competition. These include increasing production in the tertiary sector (information, services and symbolic goods), generating niche markets to target specific customer segments, creating (ever) new forms of (material or symbolic) added-value to differentiate products from other similar goods, and introducing flexible modes of production to be able to tap into new sources of "cheap goods or labor, niche markets, or sources of distinction" (Heller \& Duchêne 2012a, 9). The need to create ever new forms of distinction leads to increased efforts to commodify, which in practice is, as suggested above, a cultural, i.e. discursive and semiotic process of marking things as being certain kinds of things, different from others (Kopytoff 1986, 64).

The new economy contributes to the mobility and global circulation of people, goods, ideas and more, which has been identified as the hallmark of the contemporary era of globalisation (e.g. Appadurai 1996; Blommaert 2010; Coupland 2010; Pietikäinen 2010). At the same time, however, it urges us not to lose sight of the fact that these flows do not span the globe in equal measure, as Thurlow and Jaworski $(2010,4)$ remark. Indeed, as Bauman $(1998,2)$ notes, "what appears as globalization for some means localization of the rest", whereby "the freedom to move [--] fast becomes the main stratifying factor of our latemodern [--] times" (ibid.). Reflecting on the same point, Massey (1991) has introduced the term power-geometry to draw attention to "not only the issue of who moves and who doesn't" but "also power in relation to the flows and the movement" (ibid., 25, 26; italics in original). Theorising the spatial dimension of contemporary globalisation, Pennycook (2010), in turn, (see also Blommaert 2010) has suggested that we should view the processes of globalisation as translocal rather than global-local, thus directing the attention to how identities, practices, objects and processes relate to and traverse multiple localities while circulating across time and space - a view of particular value in the analysis of the present study. 


\section{Repression, pride, profit? A trajectory of Sámi handicraft}

The language minority Sámi people, numbering today some 60,000-100,000, are the only minority in the European Union officially recognised as indigenous people ${ }^{\mathrm{ii}}$ (Valkonen 2009, 137). The traditional residential area of the Sámi, Sámiland, covers the northern parts of Finland, Norway, Sweden, and Russia. The Sámi have a rich cultural heritage. Besides the Sámi languages, this includes a wealth of stories, legends and religious beliefs stemming from the time before Christianisation. Another vital aspect of their heritage is their traditional skill in making elaborate items for everyday use (originally) - knives, belts, pouches, shoes, dresses. Today, the Sámi word duodji refers to handicrafts made in accordance with these cultural traditions. The Sámi way of life is traditionally closely connected to nature, largely due to the traditional means of livelihoods, fishing, hunting and reindeer herding. (Pietikäinen \& Dlaske 2013; Helander 2000; Lehtola 1997; Magga 2010).

Along with many other indigenous groups, the Sámi share a history of colonial dominance and marginalisation by majority populations and later on by nation states. During two generations around the time of the Second World War the Sámi languages declined from thriving community languages to endangered minority languages. Along with the language shift came increasing cultural assimilation (Pietikäinen \& Dlaske 2013; Lehtola 1997). This trend started to change in the 1960s, a decade of cultural and political awakening, with the establishment of organisations to defend the political and cultural rights of Sámi. One such organisation was the Finnish Sámi Handicrafts Association, later renamed as Sámi Duodji. The main aims of the association were, and still are, to guarantee the continuation of the Sámi handicraft tradition and to distinguish the real Sámi duodji from the increasing "tourist knickknacks" (Lehtola 2006, 7). For this purpose the association took into use the inter-Nordic Sámi Duodji label in Finnish Sámiland (Lehtola 2006). The label, still used today, is granted to handicraft makers whose products are regarded as authentic Sámi handicrafts. To qualify for the label the producer must be recognised as Sámi. The products have to be made for traditional purposes using traditional materials (e.g. wood, leather or bone) and traditional methods (e.g. sewing by hand) (Sami Duodji Ry 2010). Born out of the spirit of ethnic awakening, the Sámi Duodji institution is characterised by a strong sense of collectivism; making Duodji is regarded, as Sigga-Marja Magga (2010, 43) notes in her study on the development of Sámi handicrafts, as an individual act for collective continuity. The influence of the Duodji institution is still strong. Magga $(2010,66)$ talks about the "Duodji hegemony" against which all activities related to Sámi handicraft are measured.

As the initial protective aim of the Sámi handicrafts association indicates, the commodification of Sámi culture is not in itself new, but is rather part of a long-standing debate in the Sámi community (cf. e.g. Pietikäinen \& Kelly-Holmes 2011). What is new are its diversifying modes and expanding opportunities arising out of the expansion of the tertiary sector. As in many other peripheral minority language contexts (cf. e.g. Pujolar \& Jones 2012 , 102) Lapland is suffering from the loss of investments, basic services and population. The solution to the problem of how to support the region is sought in the promotion of entrepreneurship, especially in the areas of tourism and handicrafts. Through this development, handicrafts have become increasingly linked to tourism; the vast majority of local arts and crafts, including Duodji handicrafts, are sold to tourists (Miettinen 2006; Pietikäinen \& Kelly-Holmes 2011).

The village of Inari, located some 300 kilometers north of the Arctic Circle, is a growing Sámi tourism centre. It is also the main cultural and political centre for the Sámi in Finland. In the autumn of 2012 Inari hosted the third seminar of an inter-Nordic seminar series entitled Yrityskehitystä rajattomalla Saamenmaalla ('Business development in the borderless Sámiland'), organised by a Norwegian polytechnic and targeted at tourist, 
handicraft and other small entrepreneurs in northern Lapland. One of the invited speakers in the seminar was the Sámi artist and entrepreneur introduced briefly above. We will call her Pia. Talking under the heading Tuotekehitystä - ruoka, matkailu, saamenkäsityöt - minun versioni ('Product development - food, travel, Sámi handicrafts - my version') she introduced aspects of her various activities, offering insight and inspiration to her peers. She spoke at some length about an ongoing charity project which she had organised for the women of an indigenous people on the border of Thailand and Laos, a project that resulted in a collection of paper products including, besides bags, lamps and boxes, a range of notebooks, now on sale in her two handicraft shops in Lapland. It is this range of notebooks, a multifaceted intersection of social processes, that forms the core of the following analysis.

\section{Methodology and study data}

To explore the reconfiguration of pride, profit and power relations in the realm of Sámi handicrafts under contemporary globalisation, the study combines an ethnographic approach with critical multimodal discourse analysis (Blommaert 2005, 2010; Heller 2008; Pietikäinen 2010; van Leeuwen 2008). The data used in the study were collected on six intensive fieldwork trips (2011-2013) to Inari, where Pia runs a guesthouse, a handicraft shop and a variety of other tourist activities. On each trip I stayed in Pia's guesthouse, which gave me the opportunity to make ongoing on-site observations and have informal conversations with Pia and her workers and guests, thus gaining insight into everyday life in the guesthouse and the shop. In the autumn of 2012 I also attended, at Pia's suggestion, the above-mentioned entrepreneurship seminar in Inari. The collection of notebooks was chosen as the focus of the study on the basis of this intensive engagement with the different aspects of Pia's activities, and especially her handicraft production. The data consist of informal discussions and three interviews with Pia ${ }^{\text {iii }}$, field notes on my observations and photographs from the site, together with selected items from Pia's artistic production, e.g. postcards and one of her notebooks. Besides these ethnographic data, the study made use of media material, such as websites.

To analyse the semiotics of the range of notebooks in terms of multidimensional connectivity and multiple meanings and functions, the study draws on two frameworks: the concept of indexicality (e.g. Blommaert 2005; Silverstein 2003) and the view of discourse as recontextualised social practice (van Leeuwen 2008). Indexicality has been defined as the social meaning of signs, in other words, as "meaning that emerges out of text-context relations" (Blommaert 2005, 11, 252). In recent sociolinguistic studies the notion of indexicality has been used to investigate meaning making, among other things, in relation to gender and other identity markers, attitudes as well as (dis)identification with social and political groups (e.g. Blommaert 2007; 2010; Karrebaek 2012; Reyes 2011; Sclafani 2009). The framework for analysing "discourse as recontextualized social practice" was first put forward by van Leeuwen (2008; see Pennycook 2010 for a further appropriation). Despite the emphasis on connections between discourse and social practice, van Leeuwen's approach, building on the tradition of Critical Discourse Analysis (CDA), remains largely text-oriented, and the connections to the social practices recontextualised in discourse to a large extent notional (cf. Blommaert's (2005) critique of CDA). To be able to get at the actual social practices and thus to grasp the aspect of recontexualisation at a more concrete level, the present study expands van Leeuwen's approach to include an ethnographic dimension, embraced in any case in research on indexicality. Another way in which the study extends van Leeuwen's approach is to take the level of analysis from that of language (linguistics/grammar) to that of discourse (Blommaert 2010; Hymes 1996, 102) to be able to include, additionally, the dimension of the translocal circulation of discursive practices (Pennycook 2010). Before moving on to the analysis, however, let us have a look at Pia's 
various activities and her handicraft shop in Inari, in order to situate the notebooks in their contexts.

\section{The notebook collection in its ethnographic context}

Having several roles and occupations is by no means uncommon in Sámiland today. Even in this context, however, Pia stands out. For one thing, she is an entrepreneur running guesthouses, tours offering popular tourist experiences, and handicraft shops in Inari and northern Norway. Additionally, she is a craftswoman and artisan, making and designing handicraft products ranging from traditional Duodji to home decoration, jewellery and ceramics, which she sells under her own labels. She is also an artist and has exhibitions of her painting in Finland and abroad. Pia is an extraordinarily inventive person, in both artistic and entrepreneurial terms, constantly developing new ideas. She grew up in the Sámi community in northern Finland, has studied in Finland and abroad, and currently lives mainly in Inari. However, she often travels, and her trips to different places around the world, often to other native peoples ${ }^{\mathrm{iv}}$, form an integral part of her lifestyle. This mobility is often reflected in the transcultural nature of many of her activities, especially in her guesthouse (cf. Kauppinen 2014). At the same time Pia's activities are directly related to her identity as Sámi, as is indicated in an advert describing her exhibition of paintings in Helsinki, entitled Ethnonaivistic Paintings, as follows:

[Pia's full name] is a Sámi artist who lives in Inari. Her art expresses strongly her Sáminess reflected both in the strong colours of the paintings and their contents relating to the Sámi narrative heritage. Foxes and wolves run in the works of this new generation's Sámi artist and the mythical sun lights the future better times for the culture. (Menoinfo, no date; present author's translation from Finnish).

Despite its status as a local centre, Inari is a small place, with only some 750 inhabitants (cf. Pietikäinen \& Kelly-Holmes 2011) and only one main road running through the village. In a landscape with relatively few buildings, Pia's red wooden guesthouse and handicraft shop, currently located next to a Duodji shop, stand out clearly beside the main road. The handpainted sign "Käsitöitä - Crafts" and a large shop window invite passers-by to go inside. Entering, the visitor - typically a German, French, English, Japanese, or Finnish woman discovers two rooms. Both are packed with colourful handicrafts - bags, pouches, jewellery, ceramics, laptop cases, napkins, postcards and more. Most of the products are sold under the label Nature Co, the largest of Pia's labels, with the caption Unique Contemporary Sami Design. Also the range of paper products is attractively displayed: lampshades in one corner, piles of boxes in another, bags (for wine bottles) hanging on a rack, the range of notebooks laid out on a shelf. The range includes books of different colours and sizes; they are wrapped in plastic with a label inside. Besides being the first items produced in the range of paper products, the books are also semiotically richest, due to this label. This is why the following analysis focuses on the book collection. With regard to other semiotic features, such as colours and decorative patterns, the books are no different from the rest of the items in the range of paper products.

\section{Semiotics of the notebook collection: meanings, functions, connections}

The books, blue, red, green, lilac and beige, have hard card covers and thick paper pages. The covers are decorated with black patterns. An example is shown in Figure 1 below. 


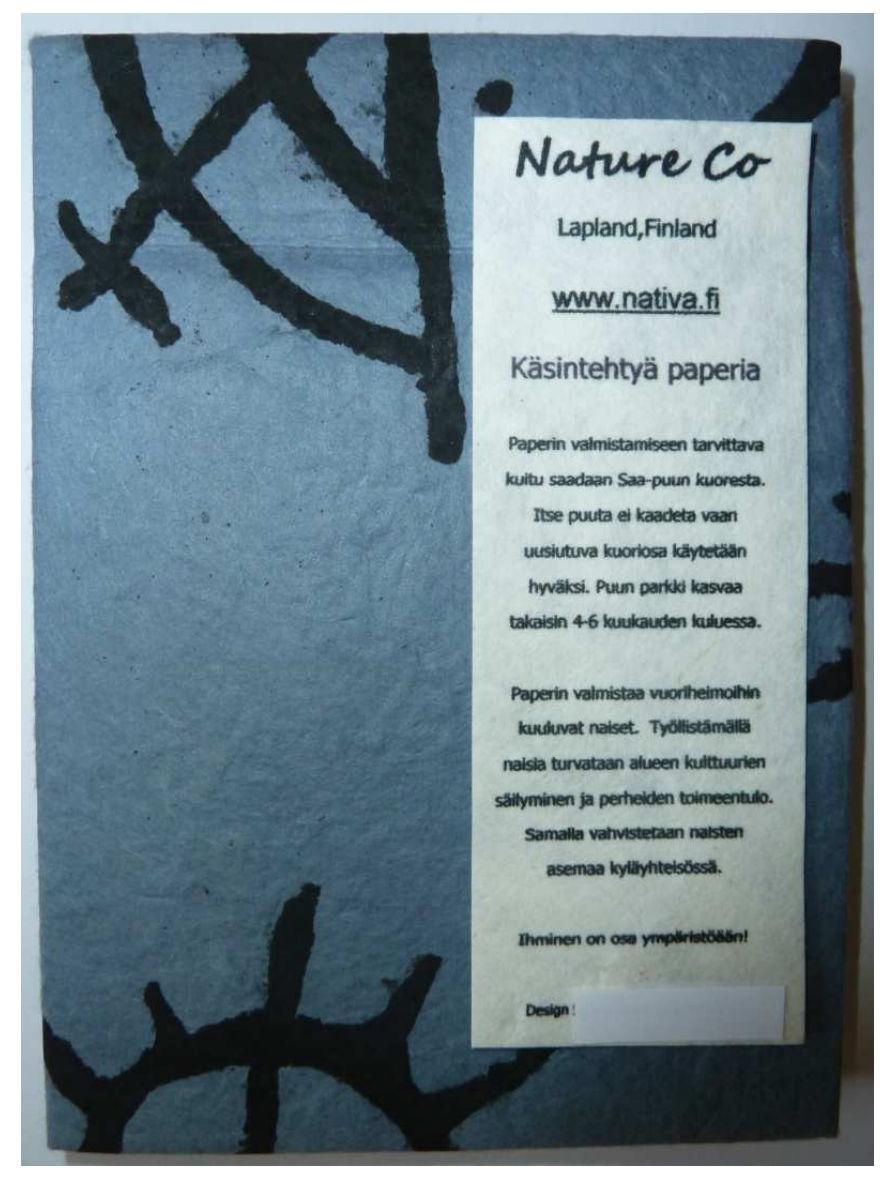

Figure 1: A book from the range of notebooks (Photo: Kati Dlaske)

The following analysis is divided into three subsections: the first subsection analyses the visual, the second and third the linguistic resources drawn upon in the semiotisation of the books.

\section{Visual resources: indexing Sáminess, rearticulating cultural heritage}

The books are decorated with one of three motifs, all of which draw quite clearly on Sámi cultural heritage. Also the colours of the covers remind one of the Sámi colours, bright red, blue, yellow and green, used in the Sámi flag and in traditional Sámi costumes. In the commercial context of a handicraft shop for tourists, the motifs and colours certainly function as indexes of Sáminess (cf. Blommaert 2010) and, by thus bringing added value to the product, as a vital means of commodification. When viewed, however, not only as an incorporation of signs, but also as a translocal recontextualisation of Sámi cultural heritage (Pennycook 2010) in the context of Pia's other handicraft and artistic practices, they stand, at the same time as new articulations of a cultural heritage and point to the trope of pride (cf. Blackledge \& Creese 2012, 118).

One of the three motifs decorating the notebooks depicting, among other things, the sun, reindeer and people on skies or in a boat, draws on imagery used traditionally on the Sámi shaman drum (see Figure 1). In pre-Christian times, the shaman drum was used in rites in which the shaman sought to contact the next world for advice. The imagery on the drum 
reflected Sámi life and beliefs and showed, like the modern notebook covers, people, animals, sacred places, shamans and the sun (Lehtola 1997). In Sámi mythology, the sun was worshipped as a god, and the Sámi people regarded themselves as children of the sun (cf. Helander 2000). Today, the sun is a motif in the Sámi flag. It is also another of the motifs decorating Pia's range of notebooks. The third motif is the fox. Fox often appears in Sámi legends as a cunning creature, and one that is capable of conveying messages to human beings (cf. Pietikäinen \& Kelly-Holmes 2011, 341).

Viewed in the context of Pia's other activities, the motifs and colours of the books appear as a translocal recontexualisation of patterns and colours she also uses in her other handicraft and art production. In her handicrafts, all three motifs recur in printed fabrics, which she uses to make her pouches, bags, laptop cases, table clothes, napkins and so on. The fox and the sun, both recognisable as Pia's artwork, are also frequent motifs in her paintings (cf. the description of the art exhibition quoted above in Section 5) and postcards, some of which are reproductions of the paintings. The significance of these two elements in Sámi mythology is explained on the back of many of the cards. All these products are characterised by the same bright colours as the notebooks. The significance of these colour choices as an expression of Sámi heritage in Pia's art and handicraft production emerges not only in the description of the art exhibition quoted above, but also from Pia's own words in one of our interviews.

To throw more light on Pia's position, let us next examine the label on the book cover.

\section{Branding: competition and contestation}

In the original, the label (See Figure 1) reads as follows:

Nature Co

Lapland, Finland

www.nativa.fi

Käsintehtyä paperia

Paperin valmistamiseen tarvittava kuitu saadaan Saa-puun kuoresta. Itse puuta ei kaadeta vaan uusiutuva kuoriosa käytetään hyväksi. Puun parkki kasvaa takaisin 4-6 kuukauden kuluessa.

Paperin valmistaa vuoriheimoihin kuuluvat naiset. Työllistämällä naisia turvataan alueen kulttuurien säilyminen ja perheiden toimeentulo. Samalla vahvistetaan naisten asemaa kyläyhteisössä.

Ihminen on osa ympäristöään!

Design [Pia's full name]

I will provide an English translation of the Finnish part of this text, essentially a trade description, in the next subsection. First, however, I want to focus on the elements that are also understandable to non-Finnish speakers. These include the brand name Nature co, the place reference Lapland, Finland, the internet address www.nativa.fi and the caption at the bottom of the label Design [Pia's full name]. All these elements can also be found in varying combinations on a number of Pia's other handicraft products, which makes them recognisable as discursive resources circulating in Pia's branding practices. 
On the one hand, the semiotic resources drawn upon for branding the notebooks index an orientation to the sphere of the new economy and more generally to global marketing. On the other, they mark a position towards Duodji, which is not only a competitive position, but one that more fundamentally challenges the ethos and practices of the Duodji institution.

The main function of brand, a key element of the new economy, is to differentiate a product from those of its competitors. Brand endows the product with particular values and associations - often encoded in the brand name - and signals its distinctive source (cf. Moore 2003). As indicated above, Nature co is Pia's main brand. In addition to this, she has a number of smaller brands. She describes herself as an 'ample' person, who cannot restrict herself to doing just one thing, although, as she adds, this would make better economic sense. Some years ago, Nature co replaced the former major brand Nativa, which is still included in the internet address on the notebook label. As the brand Nativa has ceased to exist, so too the internet address has gone out of use, and so now the address on the label only fulfils indexical functions. Besides evoking associations to nativeness, it signals up-to-dateness ('being on the web') and a global orientation. Global orientation is indexed also by the language choice for the place reference Lapland, Finland, in that English, as the lingua franca of tourism and marketing, is understandable to the widest audience, or in spatial terms, has the highest potential for global mobility (Blommaert 2010; Pietikäinen \& Kelly-Holmes 2011, 333). The denotation of this place reference, however, points to the opposite direction, namely to the local, marking this particular place as the origin of the brand. Significantly, the place mobilised in the branding is the geographical region Lapland, not Sámiland, which, although denoting more or less the same area, bears the ethnopolitical meaning of the inherited territory of the Sámi (cf. Pietikäinen \& Kelly-Holmes 2011, 336-339). Besides indexically linking the brand to Finnish Lapland, the place reference functions as a discursive recontextualisation of the place of the action of designing, captured on the label by the noun design (cf. van Leeuwen 2008, 88). The noun design and the subsequent signature mark the motifs and colours decorating the notebooks not only as a product of Pia's, but also as the product of creative, artistic activity. The signature, moreover, strengthens the sense of authenticity by creating a link to a real person as a source of the product. Although the identity of the craftsperson represents a crucial source of authenticity also in the sphere of Duodji in that she or he needs to be recognized as Sámi, the practice of highlighting the individual makers behind the products runs counter to the collective spirit characterizing the Duodji institution. Rather, then, the practice of using the signature of the designer, and drawing on the practice of and the denotation design in the first place, represent ways of creating authenticity and distinction characteristic of the globalised new economy (cf. Pietikäinen \& Kelly-Holmes 2011, 337; Magga 2010).

As noted above, these translocal practices that Pia draws on to promote brands of her own index not only Pia's orientation to the sphere of the globalised new economy, but also her position vis-à-vis the Duodji institution, marked both by competition and contestation. To explore further the latter dimension and what is at stake in it, let us hear what Pia herself has to say about her relationship to Duodji. The following extract is from an interview I had with her in the café of her guesthouse. While telling me about her handicrafts Pia is sewing a traditional Sámi sisna pouch, made from reindeer skin. Towards the end of our conversation, I ask her whether she has any overarching idea or philosophy guiding her handicraft production. "Yes", she replies instantly, "I have, two. One is this Duodji, practising and maintaining the traditional skills, and the other, is this sort of whole new world. [--] Doing Duodji is an area in its own right like within all these other things. And then", she goes on,

because I am a rebel and oppose the notion that one should only be able to do one thing, for instance Duodji, so that is why I have that protest shop. It really is a protest, within our 
community, against the notion that - damn it - we should not consent to doing just this one and only pouch a million times, over and over again, [--] that we don't stay in that prison doing for instance only this kind of thing [she shows the pouch in her hand] but that I can make for example these little printed pouches or whatever and it's like, like releasing the world from these [constraints] and then it's also about creativity...

Although Pia acknowledges, and stresses, the importance of doing Duodji as part of her own activities, many elements in the passage (e.g. highlighting her shop as a protest shop, using the exaggeration a million times, over and over again, the metaphor prison and the mild curse damn it) index a rather hostile attitude towards the institution and its regulatory practices. In particular, her frustration is directed towards the Duodji regulations on production materials and methods (cf. Section 3, above), which in her view, as the passage indicates, lead to repetition and to constraints on individual choice and creativity. Establishing a "protest shop" and brands of her own and taking a more commercial orientation have freed her from these constraints, "opened up the world" and allowed her, among other things, to experiment with different production techniques and materials. Moreover, distancing herself from the Duodji institution has enabled her to embrace methods of (mechanical) serial production and, while she is the designer, to outsource the actual manufacturing of a number of her products. The "little printed pouches" to which she refers in the extract are one outcome of this personal rebellion; the range of notebooks is another. In addition to this, the range results, as indicated above, from another strand of activities central to Pia's life, namely her travels around the world and charity projects among other indigenous groups. To attend to this dimension, let us return to the label on the cover of the notebooks, the part of the text written in Finnish.

\section{Recontextualising production practices}

The part written in Finnish gives information on the product. For non-Finnish speaking customers this passage arguably has the effect merely of visually indexing belonging to place (Lapland/Finland) which, by contributing to the sense of authenticity and exoticism attached to the product, increases its value in the tourist market (cf. Pietikäinen \& Kelly-Holmes 2011, $333,338)$. With regard to the Finnish-speaking audience its functions are, however, more varied. Translated into English, the passage reads as follows:

Handmade paper

The fibre needed for the production of the paper is obtained from the bark of the saa tree. The tree itself is not felled, but what is used is the regenerating bark. The bark grows back within 4-6 months.

The paper is made by women belonging to mountain tribes. Employing the women secures the preservation of the regional cultures and the livelihood of their families. It also strengthens the position of the women in their village communities.

People are part of their environment!

The passage draws on a variety of indexical meanings to enhance the desirability of the product. At the same time, while giving an account of the production it recontextualises a number of both material and discursive social practices. Investigation of these connections sheds light on another, intricate configuration of profit, pride and power relations.

To examine this in more detail, let us first look at the heading of the product information, the phrase käsintehtyä paperia 'handmade paper', and focus on the attribute käsintehty 'handmade'. In terms of its indexical potential, the attribute has at least three functions. Firstly, as a trope indexing authenticity and uniqueness (Pietikäinen \& Kelly-Holmes 2011, 
341), it works to create distinction and bring added value in the contemporary era of mechanical mass production. Secondly, appearing on products on sale in a handicraft shop in Inari, the attribute links the notebooks to other handmade products, making them one among other handicraft products available in this and other handicraft shops in the village. The third indexical function derives its meaning potential partly from the subsequent description of the production process and the concluding exclamation. The description is fairly general: the actions are expressed in the passive voice, and information about by whom and where the production takes place is not given (cf. van Leeuwen 2008, 28-32). As such, the representational mode is in almost complete contrast to the representation of the place associated with the brand and design and to the representation of the designer, which are both characterised by a high level of specification (Lapland, Finland; the designer's full name). By virtue of this generality, I would suggest, the description comes to represent first and foremost the notion of ecological production, or sustainable use of natural resources, and, in so doing, to index ecological consciousness. The exclamation Ihminen on osa ympäristöään! 'People are part of their environment!' and the attribute käsintehty 'handmade' contribute to the same aim. As a demonstration of ecological consciousness, the description represents an instance of the translocal discursive practice used widely in the domain of marketing to promote products ranging from automobiles to alcoholic drinks. At this discursive level, however, the description along with the exclamation also point in another direction, namely towards Sámi cultural heritage. As noted above, the Sámi (are thought to) have a particular relationship to nature. In the Sámi tradition, humans are seen as part of the environment, similarly to animals. Emanating from this understanding, the traditional Sámi way of life is characterised by respect for and an attempt to live in harmony with nature, using its resources considerately. A recent study suggests that many Sámi young people still regard the forest as their home (Helander 2000). The considerate, or sustainable, use of natural resources is also one of Pia's guiding principles, expressed by Pia herself in one of our talks and reflected in her handicraft production. The special significance of animals and nature for her is reflected especially in her paintings (cf. above, Section 5), where also the notion of forest as home finds expression, most clearly in an exhibition entitled Metsä, lumoava puutarhani 'Forest, my enchanting garden'. On the basis of these connections, I would argue that rather than merely indexing 'ecological consciousness' and thus providing the products with added value, the description of the production mode and the exclamation on the label on the notebooks (along with the actual production practices) more fundamentally recontextualise, and recreate part of Sámi cultural heritage (cf. Pennycook 2010).

The general mode of description continues in the second paragraph of the text. Although the actors are mentioned in the first sentence of the paragraph, they are represented as a generalised group, 'women', specified only through the attribute vuoriheimoihin kuuluvat 'belonging to mountain tribes'. At the same time, the attribute serves as the only reference to the place where the action happens (cf. van Leeuwen 2008, 35, 41). In the second and third sentences of the paragraph constructing the legitimation or purpose for the action (ibid., 105135) presented in the first sentence and referred to in the second as the employment of the women, the social actors are excluded again through the uses of the passive. The general category women is taken up again, appearing in the second sentence as the goal, and in the third as the beneficiary of the action employment (ibid., 32-34). The cultures and the families of the area are represented as further beneficiaries. Also here, by virtue of this generalised, unspecific mode, rather than actually giving an account of any particular event, the description first and foremost indexes social responsibility, endowing not only the production but also the purchase of the product with an aura of 'doing good'.

Mobilising the notion of social responsibility has developed in recent years into a vital marketing strategy also in global corporations, the best known of which is probably the 
cosmetics company The Body Shop (cf. Dennis 1998). The account the company gives on its operation of its website (www.thebodyshop.com) bears a remarkable similarity to the description on the label of the notebooks. Subscribing to fair trade and sustainable use of natural resources, the company sources its main ingredients from ethnic communities in different parts of the world intending, in so doing, as described on the website, to support the communities and, in particular, to raise the status of the women by helping them to provide for their families (The Body Shop, 2012).

Besides this recontextualisation, or relocalisation in Pennycook's (2010) terms, of discursive practices, the description on the notebook label recontextualises a set of very material practices. To understand these, we will turn again to the ethnographic interview data. The description relates to a project, a translocal undertaking itself, which Pia has set up to improve the conditions of the women of an indigenous group living on the Thai-Laos border ${ }^{\mathrm{v}}$. The origin of the project lies in an invitation to Pia to visit this borderland region whence young women were increasingly being sold as prostitutes to Pattaya and other tourist sites. During visits to other indigenous groups, especially in southern America, Pia had engaged in similar projects well before this one. Initially, she tells me, she was not interested in Asia at all, but she decided on a visit to Bangkok to visit the region and see what things were like there. "And so", she says, "I got hooked, and now we have five women there at work making paper." About the arrangements she says further:

It was people around the queen who fixed us the means of production there so that this is a big deal although it's just about a small group there [--]. There are a couple of us who pay their [the women's] salary there all the time so that they have this job and initially the idea was that they could have become self-employed at some point but that will never happen [--] they can neither read, nor write anything so that it will never be... it will work as long as we have the energy to run it and... pay their salaries and so on but with the consequence that the women are not leaving that area any more... the mothers of small kids don't need to go any more to hang around somewhere, stay a year and come back completely wrecked and that sort of thing.

Despite their lack of skills, the women were not lacking motivation. When Pia went back there some months later she was shocked because the women had made "so damn much of that paper". "And well", she continues,

we needed to start marketing it.. and well now I have a few customers all around Europe who are buying just paper but as we are not some third-world country traders we know how to process it, too, and books like these are made just about everywhere and then we just took our cue from others and I taught them the seriprint technique.

The motifs that were to be printed on the notebooks and later on other paper products derive from those Sámi motifs discussed above. As the women are now making not only paper but whole products decorated with Sámi motifs of Pia's design, they do not have time, as Pia remarks, to make "such an awful lot of paper", "and", she adds, "we get a much better price for these." This is the only occasion on which Pia raises the trope of profit when talking about the paper project in our discussions. Rather, as with the motivation expressed on the label on the notebooks, she stresses the importance of the attempt to improve the situation of the women and the effort to contribute to the preservation of (indigenous) cultures, thus clearly linking her activity to the trope of pride. As she explains:

The philosophy I've been promoting all the time here is that in that kind of country, when we support the wellbeing of the women, so it kind of secures the preservation of the cultures, or makes it certain because it is through the family that it comes, that's how it is here but that's how it is anywhere else in the world as well. 
To recall, on the label of the notebooks, the purpose of employing the women was described as follows: "Employing the women secures the preservation of the regional cultures and the livelihood of their families. It also strengthens the position of the women in their village communities." The leading notion underlying this description, Pia's "philosophy" and ultimately the actual project, is an idea that has become hegemonic in contemporary community development and women's empowerment initiatives worldwide (e.g. Batliwala \& Danraj 2004; Keating et al. 2010); cf. The Body Shop example, above): it is the belief that giving poor women access to economic resources leads to their social empowerment (Batliwala \& Danraj 2004). Increasingly, however, this causal assumption has been criticised as a powerful gender myth (e.g. Batliwala \& Danraj 2004; Keating et al. 2010). On the notebook label, the outcomes motivating the employment of the women are presented as real and definite results. Notwithstanding this mode of presentation, what the motivation recontextualises is rather Pia's philosophy and her own experience, or the "gender myth", than any actual outcomes of the project. When asked to give examples of how the notions of cultural preservation and women's empowerment have actually materialised in the lives of the women during the course of the project, she replies:

they have been able to buy a moped and a telly, which the men want, to gain independence. Because that was the reason why they started to sell these young women, that the men wanted some kind of modern gadgets, like tellies or mopeds. But now the money came this way and they didn't need to send mummy there to work for a year and then come back..

The papermaking project has undeniably "strengthened the position" of the women in their community by saving them from being sold as prostitutes. In structural terms, however, relatively little has changed: the women still function as providers of commodities for their men, not now by selling themselves to (Western) tourists but by working in a project producing commodities for Western markets. Whether this change can contribute to the preservation of local cultures remains, in the last analysis, an open question.

\section{Conclusions}

Drawing on critical multimodal discourse analysis and an ethnographic approach, this paper has aimed at providing insight into the increasingly complex and ambivalent configurations of pride, profit and power relations in minority language communities by focusing on the realm of indigenous Sámi handicrafts and therein on the semiotics of a particularly telling site, a range of notebooks, viewed as a multidimensional nexus of social processes.

The study brings out two critical shifts, one relating to relations within the Sámi community, the other bearing on changes on a global scale. As regards the former, the move towards the trope of profit, or to put it another way, the orientation to the commercial sphere and the logics of the new economy, has many consequences: a striving for the individualisation and personalisation of the product and thus a disconnection from the collective tradition; orientation to the global market; and concomitantly, new ways of mobilising cultural symbols, places and traditions to create added value. At the same time, however, this move opens up space for creativity and choice and the opportunity to contest the Duodji hegemony and the ownership of pride within the Sámi community with the power of new brands. Thus, the way in which Pia uses colours and motifs deriving from the Sámi tradition in the production of the notebooks should be understood not only as a source of profit but also as a rearticulation of the cultural heritage, pointing to the trope of pride (Blackledge \& Creese 2012, 118). Similarly, the method of obtaining the raw material for the paper seems to be not only a way of creating added value but also a recreation of cultural values and practices. 
With regard to the second shift, the freedom in the choice of production methods provided in this emerging space makes it possible to separate design from actual production and to tap into global sources of production, as we have seen. Although the rationale underlying the paper project was geared towards the trope of pride rather than the trope of profit, in actual practice, as the analysis showed, these two become confused in a number of ways. Moreover, as increasingly emphasised in research on late-modern forms of power, a relationship of empowerment is also a power relationship (e.g. Bröckling 2007; Cruikshank 1999). In the case of the paper and notebook project, this relationship creates vectors of power from the rich north/west to the poor south/east, setting the women at the latter end into production structures familiar from the neo-liberalised, post-colonial production modes of the new economy. The new and particularly interesting dimension of this (em)power(ment) relationship runs along the axis of ethnicity: what the women at their respective ends have in common is their belonging to indigenous minority language groups, both historically marginalised by majority populations. What essentially separates them are their respective positions in the contemporary power geometry, including not only freedom to move but also control over mobility and movement (Massey 1991). Although the paper production project may not pay off in terms of pride as desired, its benevolent background creates a market advantage. Highlighting the dimension of social consciousness and the investment in pride in the semiotisation of the products effectively downplays the dimension of profit, making the products appear almost non-commercial and the act of buying a contribution to cultural and social welfare rather than an economic transaction. On the other hand, at least for some, might that not be what it is?

\section{References}

Appadurai, Arjun. 1996. Modernity at Large: Cultural Dimensions of Globalization. Minneapolis: University of Minnesota press.

Batliwala, Srilatha, \& Deepa Dhanraj 2004. Gender myths that instrumentalise women: A view from the Indian frontline." IDS Bulletin 35 (4). 11-18.

Bauman, Zigmund. 1998. Globalization: The human Consequences. Cambridge: Polity.

Blackledge, Adrian, and Angela Creese. 2012. "Pride, profit and distinction: Negotiations across time and space in community language classroom." In Language in Late Capitalism. Pride and Profit edited by Monica Heller \& Alexandre Duchêne, 116-141. New York: Routledge.

Blommaert, Jan. 2005. Discourse. A critical Introduction. Cambridge: Cambridge University Press.

Blommaert, Jan. 2007. "Sociolinguistics and discourse analysis: Orders of Indexicality and Polycentricity." Journal of Multicultural Discourses 2 (2). 115-130.

Blommaert, Jan. 2010. The Sociolinguistics of Globalization. Cambridge: Cambridge University Press.

Bröckling, Ulrich. 2007. Das unternehmerische Selbst. Soziologie einer Subjektivierungsform. Frankfurt a.M.: Suhrkamp.

Cruikshank, Barbara. 1999. The Will to Empower. Democratic Citizens and Other Subjects. Ithaca: Cornell University Press.

Coupland, Nikolas. 2010. "Introduction: sociolinguistics in the global era." In The Handbook of Language and Globalization edited by Nikolas Coupland. 1-28. Chichester: WileyBlackwell.

Del Percio, Alfonso, and Alexandre Duchêne. 2012." Commodification of pride 
and resistance to profit: Language practices as terrain of struggle in a Swiss football stadium." In .) Language in Late Capitalism. Pride and Profit, edited by Monica Heller \& Alexandre Duchêne 43-72. New York: Routledge.

Dennis, Bryan, Christopher P. Neck, and \& Michael Goldsby. 1998. "Body

Shop International: an exploration of corporate social responsibility." Management Decision 36 (10). 649-653.

Helander, Elina. 2000. "Saamelainen maailmankuva ja luontosuhde.” In Beaivvi mánát. Saamelaisten juuret ja nykyaika, edited by Irma Seurujärvi-Kari. 171-182. Helsinki: SKS.

Heller, Monica. 2003 "Globalization, the new economy, and the commodification of language and identity." Journal of Sociolinguistics 7(4): 473-492.

Heller Monica. 2008. "Doing ethnography." In Blackwell Guide to Research Methods in Bilingualism and Multilingualism, edited by Li Wei and Melissa Moyer. 249-262. Oxford: Blackwell.

Heller, Monica. 2011. Paths to Postnationalism: A Critical Ethnography of Language and Identity. New York: Oxford university press.

Heller, Monica, and Alexandre Duchêne. 2012a. "Changing discourses of language, capital and nation-state." In Language in Late Capitalism. Pride and Profit, edited by Monica Heller \& Alexandre Duchêne. 1-21. New York: Routledge.

Heller, Monica, and Alexandre Duchêne (eds.). 2012b. Language in Late Capitalism Pride and Profit. New York: Routledge.

Heller, Monica, and Joan Pujolar 2009. "The political economy of texts. A case study in structuration of tourism." Sociolinguistic studies 3(2). 177-201.

Hult Francis. 2010. "Analysis of language policy discourses across the scales of space and time.” International Journal of Sociology of Language 202. $7-24$.

Hymes, Dell. 1996. Ethnography, Linguistics, Narrative Inequality. Toward an Understanding of Voice. New York: Taylor \& Francis.

Karrebæk, Martha. S. 2012. "'What's in your lunch box today?': Health, respectability, and ethnicity in the primary classroom." Journal of Linguistic Anthropology. 22 (1). 1-22.

Kauppinen, Kati 2014. Welcome to the end of the world! Resignifying periphery under the new economy: A nexus analytical view of a tourist website. Journal of Multicultural Discourses 9 (1): 1-19.

Keating, Christine, Claire Rasmussen and Pooja Rishi. 2010. "The rationality of empowerment: Microcredit, accumulation by dispossession, and the gendered economy." Signs 36 (1). 153-176.

Kopytoff, Igor. 1986. "The cultural biography of things: Commoditization as process." In The Social Life of Things: Commodities in Cultural Perspective, edited by Arjun Appadurai. 64-91.Cambridge: Cambridge University Press.

Lash, Scott, and John Urry. 1994. Economies of Signs and Spaces. London: Sage.

Leeuwen, van Theo. 2008. Discourse and Practice. New Tools for Critical Discourse Analysis. Oxford: Oxford University Press.

Lehtola, Veli-Pekka. 1997. Saamelaiset. Historia, yhteiskunta, taide. Jyväskylä: Gummerus.

Lehtola, Jorma. 2006. 30 vuotta käsityö sydämellä: Sámi duodji ry. 1975-2005. Inari: Kustannus-puntsi.

Magga, Sigga-Marja. 2010. Vapauden rajat ja ulottuvuudet. Kirjoittamattomat 
säännöt duodjin ja saamelaisen muotoilun mahdollisuuksina ja rajoittajina. Unpublished Master's thesis. Giellagas Institute.

Massey, Doreen. 1991. "A global sense of place.” Marxism Today. 24-29.

McLaughlin, Mireille. 2013. "What makes art Acadian?" In Multilingualism and the Periphery, edited by Sari Pietikäinen and Helen Kelly-Holmes. 35-54. Oxford: Oxford university press.

Menoinfo, no date. Accessed 10 December 2013 at http://menoinfo.fi.

Miettinen, Satu. 2006. "Raising the status of Lappish communities through tourism development." In Cultural Tourism in a Changing World: Politics, Participation and (Re)presentation, edited by Melanie Smith and Mike Robinson 159-174. Bristol: Channel View Publications.

Moore, Robert. E. 2003. "From genericide to viral marketing: On 'brand'." Language \& Communication 23. 331-357.

Pennycook, Alastair. 2010. Language as Local Practice. Routledge: New York.

Pietikäinen, Sari. 2010. „Sámi language mobility: scales and discourses of multilingualism in a polycentric environment." International Journal of Sociology of Language 202: 79-101.

Pietikäinen, Sari. 2013. "Heteroglossic authenticity in Sámi heritage tourism." In

Multilingualism and the Periphery, edited by Sari Pietikäinen and Helen Kelly-Holmes.

77-94. Oxford: Oxford university press.

Pietikäinen, Sari \& Helen Kelly-Holmes. 2011. "The local political economy of languages in a Sámi tourist destination: Authenticity and mobility in the labelling of

Pietikäinen, Sari, and Kati Dlaske. 2013. Cutting across media spaces and boundaries: the case of a hybrid indigeneous Sámi comedy. Sociolinguistica 28: 87-100. souvenirs." Journal of Sociolinguistics 15 (3). 323-346.

Pujolar, Joan, and Kathryn Jones. 2012. "Literary tourism: New appropriations of landscape and territory in Catalonia." In Language in Late Capitalism. Pride and Profit edited by Monica Heller \& Alexandre Duchêne. 93-115. New York: Routledge.

Reyes, Aangela. 2011. “'Racist!': Metapragmatic regimentation of racist discourse by Asian American youth.” Discourse \& Society 22(4). 458-473.

Sami Duodji Ry. 2010. Sami Duodji -merkin säännöt, last accessed 10 December 2013 at http://www.samiduodji.com/30.

Sclafani, Jennifer. 2009. "Martha Stewart behaving badly: Parody and the symbolic meaning of style." Journal of Sociolinguistics 13 (5). 613-633.

Silverstein, Michael. 2003. Indexical order and the dialectics of social life. Language \& Communication 23: 193-229.

The Body Shop 2012. "Community fair trade paper products from Nepal". The Body Shop International PLC. Accessed 15 December 2013 at http://www.thebodyshop.com/values/Ingredient_paper.aspx.

Thurlow, Crispin, and Adam Jaworski. 2010. Tourism Discourse. Language and Global Mobility. Houndmills: Palgrave Macmillan.

Valkonen, Sanna. 2009. Poliittinen saamelaisuus. Tampere: Vastapaino.

\section{NOTES}


i Peripheral Multilingualism: sociolinguistic ethnography of contestation and innovation in multilingual Sámi, Corsican, Irish and Welsh indigenous and minority language contexts' (www.peripheralmultilingualism.fi)

ii The term indigenous people is not unequivocal. The recognition of Sámi as an indigenous people is based on ILO Convention No. 169 (Valkonen 2009: 138).

iii The interviews were conducted in Finnish. The English translations in this paper are mine.

iv The word Pia uses in this connection in the interviews is alkuperäiskansa, 'native' or 'indigenous people'. She uses the term consciously and fairly frequently, albeit often not specifying to what groups she is actually referring. In our talks, she identifies herself as a member of an indigenous people, which not only creates a sense of global belongingness but also opens up "a global horizon for action" (Valkonen 2009: 139) and grants, as she notes in an interview, access to other indigenous communities.

v Also in this connection Pia talks about alkuperäiskansa ('native/indigenous people') although she does not know exactly what group of people she is dealing with as "there are so many similar" in that region. 